\title{
Olmedo y Quintana: de la lealtad al rey a la soberanía de la nación como tensión en el discurso lírico independentista
}

\section{Olmedo and Quintana: From Loyalty to the King to Sovereignty of the Nation as Tension in the Lyrical Independence Discourse}

\author{
Johnny Zevallos \\ Universidad Nacional Mayor de San Marcos, Lima, Perú \\ Contacto: jzevallose@unmsm.edu.pe \\ https://orcid.org/0000-0002-4923-3097
}

\section{RESUMEN}

La obra poética del ecuatoriano José Joaquín de Olmedo y del español Manuel José Quintana pretenden representar la crisis política e institucional que atravesaban tanto el área andina en su tránsito del virreinato a la república como la península en su pretensión de recuperar la soberanía política tras la invasión napoleónica. Más aún, al ser partícipes, en sus calidades de diputado y de periodista político, respectivamente, durante unos de los momentos fundacionales en la organización jurídica de las naciones hispanoamericanas, las Cortes de Cádiz, es necesario acercarse a sus proyectos poéticos desde otra perspectiva. Ambos coinciden, además, en proponer escenarios que se desplazan desde el antiguo régimen hacia el sistema liberal al introducir sememas que aspiran a reproducir, en primera instancia, un discurso teológico-político que dirigía los imaginarios social y cultural para, en un segundo momento, apuntar a un estadio legal más amplio: el discurso constitucional y la ruptura del espacio imperial. Me interesa, por lo tanto, reconocer no solo las estrategias retórico-figurativas sino, sobre todo, el imaginario sociopolítico construido por la ciudad letrada en las propuestas poéticas de Olmedo y de Quintana, y cómo estas variaron de acuerdo

Recibido: 18.08.2020 Aceptado: 19.04.2021

\section{ABSTRACT}

The poetic work of Ecuadorian José Joaquín de Olmedo and Spanish Manuel José Quintana pretend to represent the political and institutional crisis that the Andean area was going through in its transit from viceroyalty to republic as well as the peninsula in its attempt to regain political sovereignty after the Napoleonic invasion. Furthermore, by being participants, in their capacities as deputy and political journalist, respectively, during one of the founding moments in the legal organization of Hispanic American nations: the Cortes de Cádiz, it is necessary to approach their poetic projects from another perspective. In addition, both coincide in proposing scenarios that move from the old regime to the liberal system by introducing seminars that aspire to reproduce, in the first instance, a theologicalpolitical discourse that directed the social and cultural imaginaries for, in a second moment, aim at a broader legal stage: the constitutional discourse and the rupture of the imperial space. Therefore, I am interested in recognizing not only rhetorical-figurative strategies but, above all, the sociopolitical imaginary constructed by the lettered city in the poetic proposals of Olmedo and Quintana, and how these varied according to the irruption of renewal aesthetic-political models, product of Cadiz constitutional pattern, and that 
con la irrupción de modelos estético-políticos renovadores, producto del patrón constitucional gaditano, y que desencadenará en los diferentes movimientos independentistas en Hispanoamérica.

Palabras clave: José Joaquín de Olmedo; Manuel José Quintana; Poesía; Discurso político; Liberalismo

\section{Introducción}

El presente artículo pretende establecer una nueva interpretación de los poemas "El árbol" y "La marcha" de Olmedo a partir de la relación entre un discurso poético renovado por las Cortes de Cádiz y la transformación del lenguaje político en el mundo hispánico a comienzos del siglo XIX. Al respecto, se pretende corroborar ambas producciones líricas con dos poemas del español Quintana: "A España, después de la revolución de marzo" y "Al armamento de las provincias españolas. Contra los franceses", en cuanto textos que invocan a una identidad hispánica que anunciaba ya la desarticulación del otrora espacio imperial. El discurso poético tendrá como fin, para ambos autores, anunciar la ruptura inminente de un espacio imperial utópico frente a la intromisión de un nuevo lenguaje político y cultural que permitió socavar una aparente unidad territorial.

En tal sentido, el año 2021 constituye una fecha significativa para la política identitaria y utópica de la comunidad imaginada criolla peruana. El surgimiento de la república como sistema de gobierno atravesó diferentes estadios durante 200 años, lo que significó, en principio, la consolidación del liberalismo como práctica social e ideológica en Hispanoamérica y, después, un concepto asociado a la igualdad de derechos y los mecanismos de representación (McEvoy, 2009, p. 1345). De esta manera, se gestaron cantos e himnos patrióticos que contribuyeron a imaginar la nación peruana a partir de patrones diseñados por la propia élite criolla que consiguió la independencia. Cabe advertir, sin embargo, que los cambios políticos que trajo consigo la independencia peruana del dominio peninsular no se iniciaron en la segunda década del siglo XIX; en 1809 empezaron a gestarse juntas de gobierno que emplearon códigos jurídicos y soberanos que permitieron, primero, rechazar al rey usur- will unleash in different independence movements in Hispanic America.

Keywords: José Joaquín de Olmedo; Manuel José Quintana; Poetry; Political discourse; Liberalism

pador José I del espacio imperial hispánico para, después, fortalecer una identidad propia en cada reino ultramarino. Aun en esos años la imagen del rey permanecía incólume entre los súbditos españoles, tanto peninsulares como americanos. Durante los años de crisis de la monarquía, la presencia del rey no estaba precisamente en cuestión, sino la forma de gobierno que este ejercía en las dos orillas del Atlántico.

Estas juntas fueron réplicas de las que se formaron en la Península Ibérica. Un verdadero avance dentro de esta nueva política de las Cortes fue la convocatoria de los hombres más ilustres de cada región del imperio español, incluidos los virreinatos americanos, a quienes se les otorgó el título de diputados suplentes. Se entendía que, al estar ocupado el territorio español, debía elegirse entre los vecinos nacidos en tierras americanas junto a aquellos residentes en Cádiz que podían ocupar ese cargo. Por ello, se decidió convocar a sufragio en los propios virreinatos y demás reinos a diputados propietarios que arribarían posteriormente a la Península. El establecimiento de diputados americanos significó una revolución en la forma de hacer política en ambas orillas del Atlántico, pues se entendía que tanto peninsulares como criollos tenían, como funcionaba así precisamente, los mismos derechos y deberes para la corona.

\section{Un criollo a las Cortes de Cádiz}

José Joaquín de Olmedo fue elegido diputado por Guayaquil en 1810, en elecciones realizadas en el virreinato del Perú para las Cortes de Cádiz. Juró el cargo de diputado el 2 de octubre de 1811 (Berruezo, 1986, p. 139). Fue un acontecimiento revolucionario, dado que era la primera vez que los pobladores criollos e indígenas elegían a sus propios representantes. Permaneció en la ciudad gaditana como representante hasta el 10 de mayo de 1814 (Rieu-Millan, 1990, 
p. 44). Esta experiencia parlamentaria fue, sin duda, interesante, ya que le permitió vivir de primera mano las discusiones legislativas y las opiniones de sus colegas americanos y peninsulares. Incluso, se menciona que "[1]as discusiones sobre el estatuto de los diferentes grupos humanos de América fueron acaloradas y hasta violentas" (Rieu-Millan, 1990, p. 107). Se trata, por ello, de un momento sumamente intenso que conducirá a opacar el poder ilimitado del rey y brindar más espacio a la nación como artificio cultural y simbólico que representaba a toda la población. Es decir, en la creación lírica del diputado guayaquileño se advierten las polémicas jornadas que significaron la captura de Fernando VII y su cautiverio en Valençay (Francia), así como las intensas coyunturas políticas y de debate en Cádiz. De esta manera, el lenguaje y la cultura políticas que surgieron en el hemiciclo gaditano le sirvieron de materia para producir una obra poética que recogía estas nuevas voces y propuestas. El discurso que empleará Olmedo se alejará entonces del proceso anterior y buscará adaptarse a los cánones de legitimidad y orden que se establecieron con las Cortes y lo que ello significaba.

El cautiverio del rey Fernando VII constituyó para España y América el ingreso hacia un proceso de conmociones sin precedentes en la administración política de la Península y sus colonias. La soledad en que se hallaba la monarquía, sin su protector y soberano, hace ver al yo poético - en el poema "El árbol"- la catástrofe que representa dicho acontecimiento para la comunidad hispánica. La unidad del reino podría desmoronarse sin el tronco que une a los españoles de ambos mundos. Olmedo advierte, en los primeros diez versos, que la ausencia del rey supondrá un caos irreversible en los reinos ibéricos, por lo que al afirmar su reverencia a la figura del monarca se evidencia todavía la fidelidad de los americanos:

A la sombra de este árbol venerable donde se quiebra y calma

la furia de los vecinos formidable, y cuya ancianidad inspira a mi alma un respeto sagrado y misterioso, cuyo tronco desnudo y escabroso un buen asiento rústico me ofrece, y que de hojosa majestad cubierto es el único rey de este desierto, que vastísimo en torno me rodea. (Olmedo, 1947, p. 49; cursivas del original)
La figura ausente de Fernando VII, en cuanto tronco que cubre el "vastísimo desierto", es el punto de partida del lamento del poeta. Se trata de un espacio amplio en sí mismo, que es descrito como vacío tras la desaparición del rey ante sus súbditos, de manera que son estos quienes se acongojan frente a la ausencia. De hecho,

[1] a lealtad centenaria del pueblo español al sistema monárquico permanecía indemne en España, y también en América: cuando las noticias de que el rey ha sido hecho prisionero por Napoleón y ha estallado la guerra con Francia, cruzan el Atlántico se suceden en las ciudades del Nuevo Mundo proclamaciones de lealtad a la corona, con una intensidad que raya el delirio y el entusiasmo. (Mínguez, 2010, p. 18)

Por ello, el empleo de adjetivos como "árbol venerable" o "furia de los vientos" obedece al eje ritual de fidelidad que se le ofrecía al monarca por parte de aquellos súbditos que sentían más de cerca su irradiación, por cuanto el complemento figurativo del desierto es el sol. La instrumentalización de los emblemas mitológicos tiene su origen en la simbología monárquica renacentista italiana y francesa vinculadas con la teoría copernicana del sol como eje ordenador del universo. Así, las "alegorías geográficas - ya sean continentes, reinos o ciudades - o el propio orbe terráqueo cuando aparece, constituyen las referencias físicas que permiten el periplo solar [...] y establecen la oportuna contrapartida terrestre al orden celeste que representa el astro rey" (Mínguez, 2001, p. 207). Es en sí, una plegaria que reclama la perpetua presencia del monarca como eje central del imperio, por lo que su ausencia significaría el derrumbe del orden universal. Por ello, en los versos 26 al 36 queda confirmada la necesidad de su presencia:
¿No ves cuán ricas tornan a sus playas de las Indias las naves españolas a pesar de los vientos y las olas? Pues muy más ricas tornarás, mi musa, de imágenes, de grandes pensamientos, contiene en sí la gran naturaleza; y de tu largo vuelo fatigada vendrás a descansar, como a seguro y deseado puerto, a la sombra del árbol del desierto. (Olmedo, 1947, pp. 49-50) 
El yo poético reclama a Erato (musa de la poesía) el haber abandonado al rey y, con ello, apartarlo de ultramar, espacio sobre el cual se desdobla mediante su otro yo (el virrey) ${ }^{1}$. A través de la presencia de la musa busca transmitir los ideales ilustrados que giraban en torno a América como espacio de belleza, naturaleza e imágenes relacionadas con el aparato visual que se había construido de ultramar. De hecho, Urquijo (2020) señala que "[s]i bien el paisaje es una realidad formal, territorial y concreta, también es resultante de la proyección y abstracción de esa misma realidad: una imagen visual, narrativa, sonora o alegórica" (p. 28). En tal sentido, la propuesta discursiva busca integrar el paisaje americano para proyectar desde una figura literaria que represente a la nación. La construcción de un discurso visual que asocia el territorio con una comunidad de sujetos se dirige hacia un sentido de identidad. En efecto, "[c]iertos elementos del entorno se cargan de simbolismo y se vuelven centrales para la experiencia colectiva y para la definición de discursos de identidad” (Urquijo, 2020, p. 28).

La "gran naturaleza" a la que se refiere el yo poético es, sin duda, la América que se lamenta por la ausencia del monarca. Y es que esta podría perderse si el rey no retorna a administrar los reinos hispánicos. El secuestro del soberano español ha causado una enorme zozobra y es preciso que la musa realice este viaje ficcional, ya que se necesitaba recobrar el espíritu del heroísmo helénico que había unido a la España del Siglo de Oro. Olmedo participa de esta forma de comprender la política unitaria hispánica y cuestiona la interrupción del orden monárquico peninsular en favor de la tiranía bonapartista. En los versos 57 a 75, el poeta guayaquileño reclama la necesidad de imponer las leyes tradicionales españolas en lugar de reconocer el interés francés:

Los pueblos sabios, libres y virtuosos en el trono sentaron a las leyes, y se postraban a sus pies los reyes. Pero el tirano, no: sentóse él mismo, y las leyes sagradas puso a sus pies sacrílegos postradas. Y nada perdonó para su intento: su valor, su talento, aun las virtudes mismas le sirvieron, y tenidas en máximas de Estado su respetable máscara le dieron.
Vióse la religión inmaculada, hija del cielo noble y generosa, sierva de su política insidiosa; y el grande protector de la fe santa, con suma reverencia, los Evangelios en París decora y el Alcorán en el Egipto adora. (Olmedo, 1947, pp. 50-51)

El poeta se muestra contrario a las ambiciones del impostor francés y, por ende, de los ideales revolucionarios; resalta, entonces, las leyes españolas como auténticas para legitimar la autoridad en el universo hispánico. Se trata de reconocer el poder de las leyes tradicionales, establecidas desde los Reyes católicos, como un conjunto de normas que "son las que arreglan la forma del Estado y son es decir, están [sic], por así decirlo, sobre el mismo legislador, no pudiendo o no debiendo éste tocarlas, porque de ellas recibe la investidura tal" (Ibáñez de la Rentería, 1994; como se citó en Tomás y Valiente, 2011, p. 43). Efectivamente, era el pueblo el más cercano a reconocer el poder monárquico y a defender las leyes fundamentales, porque constituyen el pilar sobre el que se erige el Estado. El hecho de anteponer las leyes sobre la investidura del rey explicaba el poder limitado de este dentro de la estructura política peninsular. El problema político de 1808 generó una inminente crisis de identidad en ambas orillas del Atlántico debido a que supuso el descabezamiento de la monarquía absolutista, e inició los movimientos emancipadores en ultramar, y con ellos la desarticulación del cuerpo político hispánico en América. Quienes impulsaron la reacción separatista de la unidad hispanoamericana se basaron en la evidente crisis de identidad en que se sustentaba la misma monarquía, pues había surgido el debate imperioso sobre si se trataba de un territorio unitario o plural (Guerra, 2003, pp. 128-129). Mientras los peninsulares sostenían que la corona era unitaria, es decir, excluían la integración de los antiguos reinos, para los americanos se trataba de un régimen pluralista, que sí debía reconocer los derechos de los ultramarinos de participar en los destinos de la monarquía (Guerra, 2003, p. 129). Esta visión renovadora que muestran ambos poemas puede notarse en los versos siguientes. Así, por ejemplo, Olmedo señala, en "El árbol", cómo los sucesos en España eran sentidos tan íntimamente por los americanos que exhiben su dolor de manera similar a los peninsulares: 
¡Ay! ¡Qué la tierra toda estremecida tiemble por donde pasa y brota sangre! ¡Qué nuevo crimen! ¡Dios! ¡Oh madre España, tu fe pura y entera,

y tu misma virtud cuánto te daña!

Un corazón virtuoso, noble, fiel, generoso, no sospecha jamás que se le engañe. ¡Oh traición inaudita!... Las montañas desplómese y en polvo se deshagan. (Olmedo, 1947, pp. 51-52)

Se presenta a la nación peninsular como el ente a quien se dirige para exponer su protesta frente a las crisis política y social suscitadas tras la invasión francesa. Los acontecimientos entre franceses y españoles servirán para identificar a la comunidad como parte de una unidad territorial y, a la vez, abstracta, que debía servir de cohesión a peninsulares y americanos. Era perentorio pensar entonces que la lucha contra los invasores franceses fuera también replicada en ultramar, porque

[1]os promotores de las juntas americanas valoraban, por tanto, de manera muy positiva la revolución de las provincias de España, entendiendo que la crisis requería la formación de tales cuerpos políticos por haber afectado justamente al 'primer eslabón' de todo el mecanismo monárquico hispano. (Portillo, 2006, p. 64)

$\mathrm{Al}$ ser España el núcleo de la lucha de independencia ante las fuerzas bonapartistas, este será tomado como modelo por los ultramarinos al identificarse, primero, con la causa peninsular para luego volverse contra ella. Las Cortes de Cádiz y la Constitución de 1812 constituirán el modelo de arraigo político de los americanos; asimismo desencadenaron el desmembramiento del imperio español a través de "la introducción del sistema representativo para elegir a los nuevos ayuntamientos constitucionales, cuestión que inevitablemente abrió las puertas al enfrentamiento entre facciones políticas" (Ossa, 2014, p. 255).

En los versos expuestos a continuación se observa al yo poético dirigirse a los españoles como una sola nación, conformada por los hombres de ambos hemisferios, identificados con la ciudadanía hispánica y perte- necientes a una misma bandera y un solo rey. Aunque el poeta no escapa de su mirada ilustrada al calificar a los indígenas como "salvajes", es posible afirmar la pretensión criolla de incluirlos en los debates y sugestivas querellas impuestas durante el desarrollo de las Cortes de Cádiz (Rieu-Millan, 1990, p. 109):

Nunca el indio salvaje ni el viajero, la senda en noche lóbrega perdida, tanto del sol ansiaron la salida, como impaciente el español espera mirar la luz primera que le refleje el enemigo acero. ¡Oh qué sed tan violenta de tu sangre le abraza y atormenta!... Ya en el campo de Marte sanguinoso le hará ver que en España, para vengar la afrenta de Dios, del rey y de la patria santa, cada hombre es un soldado, y que cada soldado es un Pelayo, cada pecho un broquel, cada arma un rayo. (Olmedo, 1947 , p. 53)

El yo poético no duda en juzgar al indígena desde una perspectiva influenciada por el discurso identitario anglosajón; así, al igual que sugerían los ilustrados escoceses, "quien está en América está lejos de nuestra civilización, y aunque es nuestro hermano, ha perdido nuestra sociedad que es lo que a nosotros nos constituye de modo característico, aunque, evidentemente, no lo que nos constituye de modo esencial" (Seoane, 2015, p. 119). El adjetivo "salvaje" con que se describe al indio en el texto constituye el pilar fundamental con que se construirán los discursos romántico y liberal durante el siglo XIX ${ }^{2}$, ya que se abandonará el carácter pluralista que describía esencialmente a la monarquía Habsburgo por uno más excluyente o colonialista. El yo poético invoca a la voluntad popular para defender a la nación y al rey como símbolos de identificación con el universo hispánico y, como se observará después en la carta gaditana, el autor incluye al indígena como miembro de la comunidad. Esta asociación respondería a las pretensiones de los diputados americanos establecidos en Cádiz (Olmedo era uno de ellos) de buscar reconocer los derechos de ciudadanía, incluso para indios y mestizos. Al cuestionar los conceptos de nación y soberanía que debían formar parte de las discusiones de los diputados du- 
rante las Cortes gaditanas, la defensa americana de cómo debían entenderse estos conceptos, surgió del problema del indígena como integrante de la comunidad monárquica y su inclusión en los debates y en la futura Constitución (Varela, 2011, pp. 188-190).

La monarquía hispánica es entendida como pluralista por el yo poético, lo cual legitima su posición como agente que busca impulsar el cambio de régimen en América. Involucrar a los indígenas en la comunidad hispánica significaba - en opinión de los representantes ultramarinos - eliminar algunas taras como el tributo y la mita, que impedían su real inserción política con pleno derecho (Rieu-Millan, 1990, p. 124). Ello supuso una extensa contienda de debates sobre si era factible otorgarle los atributos legales que permitieran su participación política. Sin embargo, el conocimiento que se tenía acerca de los pobladores nativos era casi nulo por parte de los diputados criollos (Rieu-Millan, 1990, p. 124). La asociación del indígena con lo salvaje y lo bárbaro se explicaría precisamente por las enormes diferencias culturales y sociales que imperaban en un dominio tan vasto y que motivó a que se catalogara a la Constitución de Cádiz como utópica, pues se trataba de "[u]n lugar inmenso imposible de determinar geográficamente, del que ni siquiera los diputados constituyentes tenían una idea certera" (Moreno, 2011, p. 34). Por otra parte, el poeta insta a los miembros de la comunidad hispánica a defender al rey y compara a los súbditos con el rey Pelayo. Este parangón con el mítico soberano visigodo obedecía a la importancia de fortalecer el ánimo de los americanos para defender a la monarquía tras la captura del rey, especialmente en ultramar, y la necesidad de incorporar a los habitantes transatlánticos en el ejército real. El llamado a integrar la armada real respondía al miedo de despertar la división del reino; en tal sentido "[1] a misma noción de unidad política mediante el vasallaje al Rey podía resquebrajarse. En momentos de severas crisis políticas y sociales se generaba una noción de comunidades americanas que estaban fuera del Imperio" (Aljovín, 2009, p. 145).

\section{La visión revolucionaria}

En el poema "A España, después de la revolución de marzo"3, de Manuel José Quintana, puede advertir- se una visión revolucionaria dentro de la comunidad política hispánica. En este texto es posible notar con mayor rigor la decepción y el hartazgo ante la pérdida de lo que fuera un poderoso imperio:
¿Qué era, decidme, la nación que un día reina del mundo proclamó el destino, la que a todas las zonas extendía su cetro de oro y su blasón divino? Volábase a occidente, y el vasto mar Atlántico sembrado se hallaba de su gloria y su fortuna. Doquiera España: en el preciado seno de América, en el Asia, en los confines del África, allí España. El soberano vuelo de la atrevida fantasía para abarcarla se cansaba en vano. (Quintana, 2001, p. 318)

El yo poético en el texto de Quintana apela a imágenes similares a las empleadas por Olmedo: en ambos discursos se pone de manifiesto cómo la grandeza de un imperio universal es derrumbada tras la incursión del ejército napoleónico. En un estudio sobre este texto, Raquel Rico (2009) sostiene que Quintana subraya el término nación como elemento articulador del poema, quizá como incuestionable búsqueda de comparar a la "nación" con la "libertad". Se canta a la libertad como figura sinonímica de identidad española, que deberá luchar no solo contra el invasor francés, sino contra un modelo político anterior que ha conducido al país al desastre. No es una crítica al sistema monárquico en sí, sino al absolutismo como cultura política, ya que era evidente que la invasión había ayudado a circular una ideología que empujaba a ver las ideas revolucionarias como renovadoras.

Los liberales peninsulares y americanos estuvieron de acuerdo con limitar los poderes del rey no solo porque mantenerlo contradecía la tesis de Montesquieu de la independencia de poderes, sino porque la monarquía "preceptivamente regulada podría ser reformada e incluso suprimida fuese cual fuese su antigüedad y su importancia en el ordenamiento social imperante" (Varela, 2013, p. 88). Desde esa perspectiva, era mucho más claro suponer que la figura del rey era importante desde diferentes aspectos. Así, para los absolutistas su presencia era necesaria para restaurar el orden y volver a los fueros naturales del derecho 
divino. En cambio, los liberales sostenían que el poder debía compartirse entre el rey y las Cortes, de manera que era esta última, representada por la nación, la encargada de proponer las leyes para el buen gobierno (Varela, 2013, p. 77). La soberanía nacional constituía, de por sí, el pilar fundamental sobre el que descansaba el sentimiento de libertad de todos los españoles (europeos y americanos); por lo tanto, era el pueblo (representado por la nación) quien debía regular sus propias leyes y conseguir de esta manera la legitimidad del poder soberano.

Incluso el yo poético, al expresar que España estaba en América y Asia simultáneamente, pretende legitimar la compleja red universalista que entendía al imperio español como una nación de naciones. El gran temor que expresa el yo poético, sin embargo, se centra en la ruptura del mundo hispánico con el arribo de las fuerzas napoleónicas y la desaparición del monarca del escenario político. Sin duda, "al ser el rey la cabeza del cuerpo político, su desaparición es el mal supremo, pues la acefalía condena a todo el cuerpo a la corrupción, es decir, a la disolución política, tanto territorial como social" (Guerra, 2003, p. 123). De tal manera, el cuerpo político hispánico era un todo que comprendía diferentes reinos. Así, esta forma de entender la monarquía constituirá la pieza clave para comprender por qué se desestructuró tan rápidamente el imperio español.

Una idea similar puede hallarse en el texto poético de Quintana, quien entendía la usurpación del trono hispano no solo como una vuelta a las leyes tradicionales, sino incluso como un enfrentamiento inevitable para reinstaurar como lucha social y política propias de un Estado soberano:

Estremecióse España

del indigno rumor que cerca oía,

y al grande impulso de su justa saña

rompió el volcán que en su interior hervía.

Sus déspotas antiguos

consternados y pálidos se esconden;

resuena el eco de venganza en torno,

y del Tajo las márgenes responden:

“¡Venganza!” ¿Dónde están, sagrado río,

los colosos de oprobio y de vergüenza

que nuestro bien en su insolencia ahogaban?

Su gloria fue, nuestro esplendor comienza;

y tú, orgulloso y fiero, viendo que aún hay Castilla y castellanos, precipitas al mar tus rubias ondas, diciendo: "Ya acabaron los tiranos". (Quintana, 2001, p. 320)

El yo poético en el texto lírico de Quintana muestra imágenes más violentas que recurren a la lucha contra el tirano francés, pero también a la tiranía borbónica. Se asume que este conflicto ya no tiene marcha atrás y simboliza el desencadenante de múltiples acciones que desembocarán en la unidad española en su lucha contra un enemigo común. Las ansias de liberarse de la intromisión napoleónica condujo a los españoles a una guerra de independencia frente a la invasión francesa. Incluso, "en el discurso patriota, independencia y libertad fueron de la mano desde un principio" (Fernández y Suárez, 2014, p. 131). Al hablarse de independencia, se entiende que esta transita hacia una soberanía moderna, pero a la vez social, a las luces de lo que ya se entendía a finales del siglo XVIII e inicios del XIX, incluso en la propia Península (Portillo y Serván, 2014, pp. 138-139). Esta lucha por la soberanía traerá consigo una nueva forma de entender las relaciones políticas y sociales y reclamará para sí el descontento que había empezado a transmitir la monarquía absolutista. Es decir, el enfrentamiento contra el ejército invasor era a su vez dirigido contra un régimen que ya se estaba desmoronando.

Un aspecto interesante para tomar en cuenta es, por otra parte, el poema de Quintana titulado "Al armamento de las provincias españolas. Contra los franceses". Este texto se relaciona con la unidad hispánica que ya proponía Olmedo en "El árbol”, pues se recurre a la imagen del soldado que lucha en nombre del rey. De esta manera, el poema se inicia con un soliloquio expuesto por la divinidad a través del cual se invoca a la unidad peninsular en sus primeros doce versos:

"Eterna ley del mundo aquesta sea: en pueblos o cobardes o estragados, que ruede a su placer la tiranía; mas si su atroz porfía osa insultar a pechos generosos donde esfuerzo y virtud tienen asiento, estréllese al instante, y de su ruina brote el escarmiento." Dijo así Dios: con letras de diamante su dedo augusto lo escribió en el cielo, 
y en torrentes de sangre a la venganza mandó después que lo anunciase en el cielo. (Quintana, 2001, p. 324).

El yo poético no recurre a la musa griega para oír el clamor de la nación española, sino a la divinidad cristiana, probablemente como elemento identitario de la monarquía católica, lo que le permite defender su posición como imperio civilizador y evangelizador del mundo conocido desde el siglo XVI (Brading, 2003, p. 19). Las palabras de la deidad católica constituyen una operación dicotómica de imágenes entre franceses y españoles. De esta forma, se antepone a los primeros el adjetivo de "cobardes" para establecer una categoría valorativa que resuma la indignación ante el hecho de haber usurpado el papel del rey. El odio que demuestra el poeta a los franceses contribuye a proyectar la comprensión de sí mismo a través del otro, ya que "el odio involucra la negociación de una relación íntima entre un sujeto imaginado [...], el yo proyecta todo lo que es indeseable en el otro" (Ahmed, 2017, pp. 87-88). Es decir, el colectivo hispánico descubre su identidad desde la aversión al invasor, construye imaginariamente un francés tiránico, en principio, para, posteriormente, comprender la opresión en conjunto (¿absolutismo?) como enemigo de la nación.

Resulta paradójico, por ello mismo, que si bien Quintana se consideraba liberal tuviera que recurrir a imágenes del antiguo régimen, como la divinidad judeocristiana o el calificativo "augusto", en cuanto elementos intrínsecos de la épica imperial. De hecho, este discurso festivo continúa la esencia de la teatralidad barroca al dirigirse a la providencia por los infortunios que deben enfrentar los españoles por el cautiverio y, aún más, el deceso de un rey. Incluso, como lo menciona José Antonio Maravall (2012), "la muerte de una reina, siendo pérdida de tan gran tesoro para el pueblo, significa castigo divino por los pecados de éste" (p. 237). En tal sentido, al presentar las palabras de la deidad católica, el yo poético procura trasladar la comunicación con el pueblo y no con el rey, lo que constituye una ruptura con el régimen anterior. Es decir, la nación española es la soberana a la que canta la providencia, y es esta misma la que exige enfrentar a la tiranía bonapartista. El poema invoca a la unidad de todos los españoles para enfrentar la crisis política tras los hechos de 1808, por lo que la figura de la patria desplazaría en el orden jerárquico al rey. Se trataría de una aproximación a lo que se veía inevitable, ad portas de los cambios políticos que venían sucediéndose en Europa, como limitar el poder del rey para otorgárselo a la nación. De esta manera, se pensaba en liquidar el antiguo régimen hispánico, enraizado en las leyes naturales españolas, para adoptar las del país invasor. Como sostiene Joaquín Varela (2013),

[e]1 monarca, pues, no era copartícipe de la soberanía como afirmaban los diputados realistas, a partir de las tesis jovellanistas de la "soberanía compartida" entre el rey y las Cortes. Solo la nación era soberana y, por lo tanto, solo a ella, a través de sus representantes generales y extraordinarios, correspondía ejercer el poder constituyente. (p. 77)

El rey era excluido efectivamente de ejercer soberanamente el poder y le correspondía a la nación formular sus propias leyes. Los diferentes escenarios que se tejían a partir de esta premisa constituían el principal factor para establecer la división de poderes en la España preliberal, de la cual Quintana se sentía parte, y que desencadenó los futuros postulados de lo que fue la Constitución de 1812. El yo poético del poema hace hincapié en la esperanza que debe surgir de la ruina a la que ha conducido la invasión francesa y llama a la unidad peninsular para recomponer a la nación. Además, no duda en comparar a la lucha antibonapartista con la Reconquista española, ya que esta representa la contienda mítica que dio origen no solo a la identidad católica peninsular, sino ensalzó el carácter guerrero hispánico:

Asturias fue quien le arrojó primero:

¡honor al pueblo astur! Allí debía primero resonar. Con igual furia se alza, y se extiende adonde en fértil riego del Ebro caudaloso y dulce Turia las claras ondas abundancia brotan; $[\ldots]$

los ecos libradores vuelan, cruzan, encienden los campos olivíferos del Betis, y de la playa Cántabra hasta Cádiz el seno azul de la agitada Tetis. (Quintana, 2001, p. 325) 
El poeta introduce el semema "Asturias" para reivindicar la fortaleza y el empuje necesarios para recomponer la organización del reino tras la invasión napoleónica. A pesar de que la raíz del problema se centra inicialmente en cómo expulsar a los invasores de la Península, ello servirá inmediatamente después para dar nacimiento a la modernidad política requerida por todos los sectores. Al ser Asturias el foco inicial del levantamiento contra el ejército francés (Guerra, 2014, p. 157), se dirime un punto de inflexión para discutir el futuro de la monarquía tras la presencia invasora. Al mencionar "los ecos libradores", se intenta persuadir al lector sobre la perentoria unidad que viene sucediendo en todo el reino; "de la playa Cántabra hasta Cádiz" existe un empuje sólido por manifestar una unidad clara, una afección generalizada sobre la importancia de fomentar la unión a través de un sentimiento unilateral: la nación española (Guerra, 2014, p. 121).

En los versos 85 al 102 se comprueba efectivamente la noción expuesta en el párrafo anterior.

Álzase España, en fin: con faz airada
hace a Marte señal, y el Dios horrendo
despeña en ella su crujiente carro;
al espantoso estruendo,
al revolver de su terrible espada,
lejos de estremecerse, arde y se agita,
y vuela en pos el español bizarro.
"Fuera tiranos!", grita
la muchedumbre inmensa. ¡Oh, voz sublime,
eco de vida, manantial de gloria!
Esos ministros de ambición ajena
no te escucharon, no, cuando triunfaban
tan fácilmente en Austerlitz y en Jena.
Aquí te oirán y alcanzarás victoria;
aquí te oirán, saliendo
de pechos esforzados, varoniles;
y la distancia medirán, gimiendo,
que de hombres hay a mercenarios viles. (Quin-
tana, 2001, pp. 326-327)

En este fragmento puede interpretarse a la población madrileña como el agente que decidirá su futuro, primero, en nombre del rey y, luego, sin la figura monárquica. La muchedumbre interviene en el texto para reclamar la presencia del soberano a pesar de que, a su vez, ignoraba la autoridad del rey para reconocerse a sí misma como elemento primordial de una nueva autoridad política: la nación. La lucha contra la tiranía bonapartista constituye, así, la legitimación de los par- ticipantes populares activos en lugar de pasivos, ya que recompone el sistema para otorgarle la función de vigilantes y controladores del orden político. Las producciones discursivas que circulaban en la España de 1808 reproducían la manera en que la plebe peninsular veía a los invasores. Era una forma oculta de transmitir su reclamo frente al absolutismo borbónico, paradójicamente a través de la fidelidad al rey, pues, aunque la presencia del monarca era necesaria para continuar el orden, su ausencia excluía la participación política como respuesta. De esta forma, puede asegurarse que "los gobernantes y la multitud se necesitaban mutuamente, hacían teatro y contrateatro utilizándose los unos a los otros como espectadores, moderaban su respectivo comportamiento político" (Thompson, 2019, p. 121). Por ello, cabe reconocer la ausencia del rey como elemento distorsionador de la estrategia política; su presencia más bien era ineludible para (re)construir el orden que esbozaron las juntas de gobierno (en la Península y en América) en su nombre.

Es interesante observar cómo el yo poético reconoce como "sublime" la voz del pueblo, es decir, enfatiza su soberanía en cuanto factor primordial de su reconocimiento. El pueblo se convertirá así en la pieza fundamental para constituir la continuidad del régimen, por lo que se establecerá como sinónimo de nación. De esta forma, tanto la figura del rey como la del pueblo serán necesarias para garantizar el funcionamiento de la monarquía hispánica ante la invasión francesa (Fernández y Fuentes, 2002, p. 586). El papel del rey, como elemento central sobre el que se erigía el sistema político en el universo hispánico, se debilitará frente a la nación, enmarcado en las juntas provinciales y en las Cortes (Annino, 2003, p. 165). El yo poético, además, sanciona el rol de los ministros frente a los invasores al traicionar a la monarquía, que a principios del siglo XIX todavía se confundía con el término patria. Esta operación discursiva de asociar a la patria con el rey empezará a resquebrajarse con el ingreso de las ideas ilustradas, sobre todo tras los incidentes de la Revolución francesa, y, especialmente, de la invasión bonapartista (Fernández y Fuentes, 2002, p. 514).

\section{Rey, nación y libertad}

El liberalismo hispánico se vio forzado a absorber la terminología revolucionaria francesa a fin de garan- 
tizar el orden político y social resquebrajado por la crisis borbónica, las ideas impulsadas por la misma Revolución de 1789 y las aspiraciones de los otrora súbditos que buscaban incorporarse al sistema sociopolítico que imperó en Europa tras la Ilustración. Términos como ciudadanía, elecciones, soberanía, constitución, etc., en un entorno como el de la España de 1808, suponían un acontecimiento renovador e irreversible, vistos los sucesos ocurridos en los Estados Unidos y en Francia. No obstante, había quienes impulsados por la oleada revolucionaria se mostraron de acuerdo con la invasión e incluso la promovieron. Por ello, el yo poético no duda en llamar "mercenarios viles" a los afrancesados, a quienes el imaginario popular adscribe categorías despectivas y se les asocia con el oportunismo, la traición y el servilismo hacia los invasores. Además, serán aquellos quienes emplearán este término para desacreditar las reformas iniciadas por los liberales durante los debates en Cádiz, lo que se acrecentó después del retorno del rey. Por el contrario, los liberales se mostraron adversos al "colaboracionismo" (Fernández y Fuentes, 2002, p. 75) de los afrancesados y también los consideraron enemigos de los intereses de la nación al ser considerada esta, según el artículo segundo de la Constitución de Cádiz, "libre e independiente, y no es ni puede ser patrimonio de ninguna familia ni persona"4 (Moreno, 2011, p. 228). Esta idea se entiende por la pugna independentista que estaban librando los españoles en su conjunto, lo cual incluía a liberales, absolutistas y americanos. El yo poético no escapa a esa realidad e introduce, ya al final del poema, un canto a la libertad:

Suba, y España mande a sus leones volar rugiendo al alto Pirineo, y allí alzar el espléndido trofeo, que diga: LIBERTAD A LAS NACIONES.

Tal es, joh pueblo grande!, joh pueblo fuerte!, el premio que la suerte a tu valor magnánimo destina.

Así resiste la robusta encina al temporal; arrójanse silbando los fieros huracanes, en su espantoso vértigo llevando desolación y ruina; ella resiste. Crece el furor, redoblan su pujanza braman, y tiembla en rededor la esfera: ¿qué importa que a la verde cabellera este ramo y aquél falte, arrancado del ímpetu del viento, y luego muera? Ella resiste; la soberbia cima más hermosa al Olimpo al fin levanta, y entretanto, meciéndose en sus hojas, Céfiro alegre la victoria canta. (Quintana, 2001, p. 331)

El león al que hace referencia el yo poético en el poema es la representación de la monarquía hispánica y que luego simbolizará a la nación española (Mínguez, 2004, p. 87). Sin duda, el imaginario popular peninsular conservaba aún la presencia del fiero animal como símbolo de la unidad hispánica. Incluso, se suele representar a este felino en la heráldica y los discursos pictóricos del monarca peninsular (Mínguez, 2004, pp. 87-88 $)^{5}$. Este discurso simbólico del poder panhispánico tiene como base el retrato del monarca en cuanto baluarte de la identidad regia en ambas orillas del Atlántico y núcleo de las soberanías peninsular y americana. Fernando VII constituirá la figura por la cual se luchará, en un principio, como único rey reconocido por el pueblo hispánico y sobre el que recae la identidad soberana. Incluso en ultramar, las juntas de gobierno velarán por su nombre originalmente para después luchar contra él en los procesos emancipatorios americanos. Además, en la introducción a la Constitución de 1812 se dejó en claro que Fernando era, "por la gracia de Dios y de la Constitución de la Monarquía española, Rey de las Españas" (Moreno, 2011, p. 225).

Sin embargo, la realidad americana era distinta de la peninsular y reflejaba las contradicciones y el desconocimiento mutuo. El yo poético asume las naciones hispánicas como un ente homogéneo ${ }^{6}$, hecho que será cuestionado definitivamente por los diputados ultramarinos que se reunirán en Cádiz. El afán político de los liberales peninsulares era mostrar la unidad española a toda costa, incluso ignorando aquellas posturas científicas que ya afirmaban las diferencias sociales, geográficas y culturales que se apreciaban en el vasto territorio imperial (Rieu-Millan, 1990, p. 87). Llama la atención, ciertamente, esta visión despectiva de ultramar de parte de Quintana, poeta a caballo entre las ideas renovadoras de la Ilustración y el liberalismo constitucional. No hay duda, por ello, de que el liberalismo peninsular tuvo intere- 
ses distintos respecto del americano, hecho que contribuirá a la desintegración del imperio español. Los diputados indianos percibían una realidad diferente; les interesaba mostrar la compleja red de interacción entre los agentes étnico-culturales que conformaban el imperio español, entre ellos los indígenas.

$\mathrm{Al}$ contrastarse esta versión con el poema, puede advertirse que los indígenas no formaban parte del imaginario peninsular; por el contrario, se asume que la nación española es unitaria y, en consecuencia, utópica. No obstante, la homogeneización nacional (y, por ende, cultural) tuvo su origen en la Ilustración europea y, como tal, habría supuesto el triunfo de esta a partir de la incorporación de los pueblos (naciones) a la civilización occidental. Se trata de una operación político-educativa que busca persuadir, al menos en el ámbito político, sobre la pertenencia a una misma corona y, por ende, a un mismo espacio discursivo donde predomina el silencio de los "civilizados". El yo poético antepone los intereses de los liberales europeos por sobre el de los americanos para garantizar la uniformidad nacional que tanto pregonaban los peninsulares en su afán de librarse de los bonapartistas. pular del 2 de mayo de 1808, hecho que servirá de estímulo para la(s) nación(es) hispánica(s) en su afán de proclamar la lucha por restaurar el orden monárquico a través de la unidad territorial. La "pujanza" a la que se refiere en el texto simboliza no solo la fortaleza de la población panhispánica, sino que se apela también a la monarquía española como un espacio que debe mantener su unidad en un ámbito que representa, más bien, la diversidad y conglomerado de naciones. En otras palabras,

[...] la reformulación de las bases de la Monarquía y de las relaciones con las colonias producirá una notable confusión sobre el concepto de España como Imperio y nación, y sobre la $\mathrm{Na}$ ción española en relación con el pueblo - sujeto en estos años de una soberanía de facto-, con la Monarquía y con los antiguos reinos que la componen. (Fernández y Fuentes, 2002, p. 285; cursivas del original)

La España que se canta en el poema constituye un espacio desestructurado y desinstitucionalizado desde sus bases más profundas ante la ausencia del rey. Por ello, es preciso reinstaurar la monarquía, por-

\section{El problema político de 1808 generó una inminente crisis de identidad en ambas orillas del Atlántico debido a que supuso el descabezamiento de la monarquía absolutista, e inició los movimientos emancipadores en ultramar, y con ellos la desarticulación del cuerpo político hispánico en América.}

Es más, no duda en su intención de transmitir la dura realidad que deben enfrentar los españoles y los alienta en su lucha. Así, en los versos 182 y 183, puede leerse "crece el furor, redoblan su pujanza, / braman, y tiembla en rededor la esfera" (Quintana, 2001, p. 331). Los desmanes que lleva a cabo el ejército napoleónico son descritos con fiereza, por lo que recurre a imágenes bélicas que describen esperanza y regocijo. Estos sintagmas se oponen al caos y a la anarquía que significaron la presencia del usurpador. $\mathrm{Al}$ enunciar que tiembla el planeta (esfera o globo terráqueo), el poeta se advierte sobre lo terrible y violento que puede generar el enfrentamiento entre las huestes franceses y las milicias provinciales de la Península. El pueblo español se muestra prácticamente desarmado y no cuenta con las herramientas para enfrentar a su enemigo, como se atestigua en el levantamiento po- que simboliza el orden y la institución política de la nación, aunque para tal fin es necesario desechar el absolutismo. La tiranía debe dar paso a un modelo que ayude a retornar al apogeo geopolítico hispánico del siglo XVI, pero también a insertar a la nación en un esquema de interacción y cultura políticas más acordes con las nuevas ideas. De allí que entre los versos 164 y 169 se tome en cuenta al "libertador" como figura de (re)creación de un orden que contribuya al bienestar social y político: "Salve, exclamad, libertador divino, / salve', y que en ecos mil lo diga el viento, / y suba resonando al firmamento" (Quintana, 2001, pp. 330-331).

El "libertador divino" es el nuevo orden que ayudará a reconstruir el sistema político perdido tras el fracaso del absolutismo de Carlos IV y la invasión napoleónica. La convocatoria a Cortes produjo un halo 
de esperanza entre los integrantes de la monarquía recientemente desarticulada, porque constituía una representación política más auténtica, aunque en cierta forma presionada, dados los acontecimientos de emergencia. Los ideales revolucionarios no fueron eludidos ni por liberales ni por afrancesados, a pesar de sus abiertas discrepancias; uno de esos ideales que más atrajeron a ambas agrupaciones fue el parlamentarismo, cuyo aporte más significativo fue la representación de la nación misma al ser esta soberana (Fernández y Fuentes, 2002, p. 613). Las Cortes fueron, efectivamente, el espacio representativo de la participación política hispánica y significó, por ello, la voz de los integrantes de las Españas. Al argumentar que se trataba de un ente hispánico nos referimos a la búsqueda de reclamar leyes y un sistema político renovador, tal cual se hizo con las Siete partidas de Alfonso $\mathrm{X}$ el Sabio. En tal sentido, la memoria de un pasado medieval provisto de un aparato legal que estableciera - en opinión de los liberales - cierta igualdad entre todos los españoles era un sueño acariciado desde la irrupción bonapartista. Así lo sugiere Fernández (2011), ya que

[e]ran las propias Cortes las que, en ejercicio de su soberanía, decidían recuperar un hipotético pasado gótico (por mejor decir, sus principios esenciales) porque en él se habían visto protegidos mejor que nunca los derechos de la Nación. Ésta contaba, por tanto, con un poder constituyente ilimitado que le permitía aprobar en cualquier momento una Constitución a través de la cual decidía la forma de gobierno que más le conviniese, sin sujetarse a otros límites que la propia lógica de la irrenunciabilidad de la soberanía misma. (pp. 147-148)

La soberanía que emergía de la conformación de las Cortes permitió, de esa forma, la elección de sus propios representantes y ayudó a legitimar la voz de la población misma. Se trató de una libertad plena, la cual no habían tenido anteriormente los integrantes de la monarquía hispánica y ahora les permitía, como afirma el yo poético del poema de Quintana, "en ecos mil lo diga el viento, / y suba resonando el firmamento" (Quintana, 2001, p. 330). Este eco popular será vitoreado por los vecinos que habitaban en los reinos hispánicos, quienes verán con entusiasmo cómo la nación (representada por diputados elegidos en cada provincia de las Españas), y ya no el rey, determinará su propio destino. Dicha libertad se sentirá también en ultramar, donde todos los miembros de los reinos hispánicos podrán establecer su forma de gobierno y elegirán para sí, criollos, mestizos e indígenas, un control absoluto de sus territorios (Annino, 1995, p. 177). Por ello, "[f]ue una revolución silenciosa - si la comparamos con la insurgencia-, pero profunda, que modificó radicalmente el perfil de la sociedad novohispana" (p. 177). Aunque con ciertas limitaciones, los habitantes del virreinato del Perú experimentaron algunas reivindicaciones, que les permitieron ejercer un control permisivo. De esta forma, los peruanos tuvieron derecho a elegir a sus propios representantes, bajo fidelidad al rey cautivo. De esta manera, "[1]legadas las disposiciones emanadas a la Regencia, el Virrey [Abascal] cursó oficios a las diversas intendencias para que hicieran lo propio con las ciudades capitales 'cabezas de partido', a fin de que procedan a la elección de sus representantes" (Paniagua, 2003, p. 97).

En el poema "Marcha", Olmedo expondrá una posición beligerante en defensa de la soberanía monárquica hispánica y de la patria imperial española, al igual que lo hiciera Quintana en "Al armamento de las provincias españolas. Contra los franceses". Para el poeta guayaquileño, la nación y el espacio regio constituirán un instrumento de identidad mutua, lo cual se consolidará aún más con la redacción de la Constitución de 1812. Así, en el primer cuarteto, el yo poético menciona lo siguiente:
Por la patria, Fernando y las leyes, a las armas, valientes, volad; ya vencidos o ya vencedores, os espera una gloria inmortal. (Olmedo, 1947, p. 54)

No debe sorprender que el yo poético decida ubicar el sintagma "patria" antes que el nombre del rey, ya que su inclinación liberal le impulsa a determinar que aquella prevalecía sobre el monarca. En el texto, se presenta el vocablo "patria" como sinónimo de "nación", dado que hacia los primeros años del siglo XIX no estaba del todo clara su diferenciación; de hecho, hacia el siglo XVIII, y de acuerdo con los postulados absolutistas de la época, los términos patria y rey constituían una misma entidad política. De este 
modo, por ejemplo, hacia 1789, en el virreinato de Nueva Granada se afirmaba que "[1] a Patria es el Reino, es el Estado, es el cuerpo de la Nación de quien somos miembros y donde vivimos unidos con el vínculo de unas mismas leyes bajo el gobierno de un mismo Príncipe" (Finestrad, 1789; como se citó en Lomné, 2014, pp. 25-26). La patria y el rey comenzarán a disgregarse y a poseer cada una definición independiente entre sí a medida que los liberales determinan límites al poder real. Dicha interrelación de términos es lo que establecerá posteriormente la Constitución de Cádiz al sostener que

[1]a nación, pues, no se concibe como un sujeto abstracto e incapaz de actuar por sí misma. No se trata de un sujeto puramente ideal [...]. La nación puede ejercer el poder político, solo que "útilmente" precisa delegarlo por las dificultades materiales para ejercerla de manera directa. El concepto de nación se acerca, así, al concepto rousseauniano de pueblo, esto es, a un conglomerado de individuos existentes y actuantes. (Varela, 2011, p. 177)

Según la definición liberal de patria, el yo poético entiende que el rey ha perdido su origen divino y ha cedido su poder a la nación. De allí que aquel lo comparta con esta y las nuevas leyes instituidas por las Cortes, a partir de un aparato jurídico independiente de la monarquía (en lugar de las leyes fundamentales, propias del antiguo régimen), como elemento tripartito sobre el que se fundará el nuevo Estado hispánico. $\mathrm{Al}$ respecto, los diputados liberales gaditanos serán enfáticos al señalar que, de acuerdo con el tercer artículo de la Constitución, "[1]a soberanía reside esencialmente en la Nación y por lo tanto pertenece a ésta exclusivamente el derecho de establecer sus leyes fundamentales" (Moreno, 2011, p. 229). Al excluirse al rey de las competencias políticas y jurídicas, se limitaba su condición de soberano absoluto; por el contrario, se establecieron prerrogativas que definían con claridad sus atribuciones y deberes como cualquier otro soberano ${ }^{7}$.

En los dos siguientes cuartetos, el yo poético llama a los ciudadanos españoles de ambos hemisferios - es decir, su alocutario es tanto el ciudadano peninsular como el americano - a empuñar las armas para defender a la patria de la invasión francesa:
¿No escucháis en los campos vecinos

los franceses infames bramar?

¿No miráis con frenética furia

los hogares del pobre talar?

Los fuertes aceros,
patricios guerreros,
al punto empuñad.
Marchad, sí, marchad. (Olmedo, 1947, p. 55)

Se trata de un himno patriótico que tiene como tema poético el llamado a combatir a los usurpadores del trono español. El empleo del verbo "bramar" se relaciona con el alarido o grito que pronuncian los usurpadores y, por lo tanto, se les describe como "incivilizados". Durante la Ilustración era sumamente común relacionar lo incivilizado con aquello que se deseaba descalificar; de tal forma, el rugido o bramido era expresión de un símil con las - en opinión de realistas y liberales españoles - atrocidades cometidas por los revolucionarios de 1789 y con los acontecimientos sucedidos en los años anteriores al gobierno del terror de Robespierre (Fernández, 2014, p. 205). A inicios del siglo XIX, la actitud de los franceses estaba asociada con la barbarie y lo salvaje por parte de la élite conservadora peninsular, así como por algunos liberales, mas no por los afrancesados, quienes de inmediato se distanciaron de los revolucionarios y abanderaron la lucha contra la invasión. De esta manera, se creía que el universo católico, representado hasta ese momento por la monarquía hispánica, encontraba en las prácticas sociales y culturales como la francesa una profunda separación con lo civilizado, de acuerdo con los preceptos morales europeos del siglo XVIII (Fernández, 2014, p. 201). Incluso para los liberales era difícil rehuir de esa categoría, por cuanto consideraban que la nación española debía profesar la religión católica como única y verdadera (Moreno, 2011, p. 235), lo que significaba una continuidad en la identidad católica de la monarquía. Por ello, el yo poético no duda en añadir el calificativo "infame" a fin de subrayar aún más la deshonra que ha producido el usurpador en la Península.

Otra de las imágenes interesantes del poema es "con frenética furia / los hogares del pobre talar", lo que recuerda los episodios abominables cometidos por los invasores contra la población civil española. 
Efectivamente, la lucha de la plebe peninsular contra el ejército bonapartista sirvió de modelo a los pobladores americanos en su rivalidad frente a las tropas hispanas en favor de su independencia. Al respecto, las insurrecciones y guerrillas que se suscitaron para combatir a los usurpadores fueron aplaudidas y criticadas por las juntas españolas, las cuales "intentan construir desde 1808 - consiguiéndolo en 1810-, formadas de resultas de levantamientos del pueblo urbano, más o menos movilizado por miembros de las élites, [la fundación de] su legitimidad en la acción de ese pueblo y en su aprobación expresada a través de aclamaciones" (Guerra, 1991; como se citó en Sá e Melo, 2009, p. 1127). En ese aspecto, la causa popular constituye un referente de identidad nacional, por cuanto resume en sí a la nación misma y su rechazo al orden institucional imperante. Los regímenes autoritarios conducen siempre a revueltas y motines, que condicionan las interrelaciones entre quienes ejercen el poder y aquellos que se ven subordinados a él, de allí que esta relación de poder sea saboteada especialmente en escenarios de mayor dependencia social.

La nación concebida en las juntas constituía una revolución en sí misma, pues se intentaba representar con ellas la mixtura social, política y cultural que existía en los territorios ultramarinos antes de la caída del antiguo régimen. De esta forma podía observarse en dichas juntas a "autoridades en ejercicio, magistrados en las Audiencias, representantes de los cabildos civiles y eclesiásticos, miembros de las órdenes privilegiadas y de las corporaciones, militares, representantes de las ciudades de segundo orden, etc." (Demélas, 2003, p. 134). La construcción de este sistema procuraba representar, aunque no totalmente, a "patricios y plebeyos", quienes debían tomar las armas para defender la unidad peninsular. El poeta pretende, así, reproducir las voces de la sedición contra los franceses, lo que luego será tomado por los liberales americanos para contar con mayor representación en las Cortes.

En los versos 13 al 24 el yo poético expone el núcleo del poema, ya que presenta ante los americanos (su alocutario) la necesidad de luchar por la unidad de la patria española, una unidad que incluía por igual a peninsulares y americanos. Esto, sin duda, se pretende defender a lo largo del texto:
Resuena el tambor; acordes marchemos, y la sangre española venguemos derramada con ciego furor.

Cuando altiva el dominio del mundo

la señora del Tibre aspiró, y la España en dos siglos de lucha puso freno a su loca ambición, ante Asturias sus águilas sólo detuvieron su vuelo feroz, y el feliz Octaviano a su vista desmayado y enfermo tembló. ${ }^{8}$ (Olmedo, 1947, p. 55)

La "sangre española" es entendida como la esencia que une al llamado de la patria hispánica, la que en momentos de crisis necesitaba de la unión de todos sus hijos. Esta construcción abstracta era perfectamente comprendida por los individuos que conformaban la monarquía católica durante los siglos XVI y XVII, por lo que se trataba de un mecanismo político-religioso que cohesiona las lealtades entre quienes frecuentan los espacios de interacción social y política de las ciudades hispanoamericanas (Velázquez, 2013, p. 59). Estas prácticas culturales se mantuvieron incólumes hasta la primera década del siglo XIX. En tal sentido, la concepción abstracta de la fidelidad al rey y la religión eran infranqueables, y se persiguió la idea de que tanto el español europeo como el americano debían mantenerse leales ante la figura del monarca como padre de todos los integrantes de la corona. Sin duda, la dualidad "rey/padre" o "monarquía/patria" fue defendida en aquellos territorios que mantuvieron mayor afinidad con la Península, como Nueva España y el Perú, y empezó a resquebrajarse en aquellos dominios de ultramar que se consideraban apenas como satélites del universo europeo. La defensa de la patria era, a fin de cuentas, la defensa del rey, y es que

[e]sta acepción fue muy difundida durante este periodo de crisis, especialmente en Lima, y propagada por las autoridades civiles y religiosas para motivar la fidelidad a la Monarquía y el repudio a Napoleón. El sujeto convocado era el "buen vasallo" y en consonancia su patriotismo debía estar ligado a la fidelidad del soberano y la defensa de la religión católica. (Velásquez, 2014, p. 168) 
El poeta pretende mostrarse como el buen vasallo que invoca a la unidad por la defensa de la patria y del rey para contrarrestar la invasión bonapartista. $\mathrm{Su}$ alocutario debía estar persuadido de semejante empresa, por lo que su propuesta se encamina a fortalecer la nación española (incluso por encima de la figura del monarca). Por ello, no insiste en delimitar la frontera que diferencia la patria española de la americana, sino que asume que se trata de un mismo sentimiento de lealtad y de pertenencia social y cultural para los dos hemisferios, por lo que "[a]mbos dominios, el de España y América no componen ya sino una sola patria para americanos y españoles: de suerte que la España en todo sentido es para nosotros lo que la América es para los españoles" (El Satélite del Peruano, 1812; como se citó en Velásquez, 2014, p. 169). Por ello, su insistencia en convocar a una marcha patriótica tiene relación con el sentimiento de unidad que proclamaba Quintana en "Al armamento de las provincias españolas". Ambos textos presentan nexos en común a partir del sentimiento de unidad, por un lado, y una propuesta beligerante y de reivindicación del espacio regio, por otro. Pueden distinguirse, además, otros aspectos determinantes en ambas producciones líricas, como la furia del pueblo español frente a la destrucción propiciada por los franceses y la consumación de la libertad como emblema frente a la tiranía. Estas operaciones discursivas tienen como premisa el predominio de la ideología liberal por sobre el bando absolutista e imperialista. Tal idea se relaciona con el símil que desarrolla el yo poético al asociar a las pretensiones napoleónicas de dominar el orbe con las aspiraciones del Estado romano (señora del Tíber o Tibre) y a Bonaparte con Octaviano u Octavio.

Asturias es el símbolo de la resistencia y el punto de partida de la libertad, por lo que se asume que Cádiz representaría la nueva Asturias desde donde los ciudadanos españoles de ambas orillas lucharán por liberar a la nación de sus opresores. Se trata de una imagen que solo toma en cuenta el contexto peninsular y excluye la atmósfera americana, lo que podría interpretarse como una aproximación eurocéntrica de los acontecimientos, antes que registrar una perspectiva panhispánica ${ }^{9}$. Dicha operación comparativa de emblemas peninsulares constituye una herramienta discursiva que le permite al yo poético persuadir a los lectores europeos acerca de lo íntimamente armonizados que estaban los españoles de los dos mundos, por lo que no era de extrañar que podrían defender a la nación ante cualquier circunstancia. Se entendió la lucha por la independencia como un fenómeno que partiría desde la Reconquista como empresa de un objetivo político, es decir, un enemigo común para todo el reino, el cual mutó del sarraceno al francés (Maravall, 2013, p. 262). La idea de la pérdida de España y la lucha por su recuperación será el derrotero de la imagen universal que se tendrá de la Península en 1808 (Maravall, 2013, p. 288).

En el séptimo y último cuarteto es posible advertir la consecución del paradigma libertario propuesto en los versos anteriores. Se pretende así anteponer la victoria panhispánica frente al enemigo francés y enarbolar la nación española como victoriosa sobre la tiranía.

\section{Corred, corred briosos,} corred a la victoria, y a nueva, eterna gloria subid vuestro valor ${ }^{10}$. (Olmedo, 1947, p. 55)

Cabe recordar que la victoria como paradigma del triunfo político tiene su origen en las fiestas del antiguo régimen (sin duda, el yo poético aún no se habría desprendido de las estrategias discursivas del Barroco), en las cuales se representaba esta como la diosa que coronaba a los reyes. Sin embargo, Burke (2011) sostiene que su origen es más antiguo, porque "[1]a forma de la entrada real a una ciudad era una costumbre medieval, aunque había sido reconstruida en el Renacimiento según el modelo de un antiguo triunfo romano, con carros, trofeos, arcos triunfales, etc."11 (p. 191). $\mathrm{Al}$ respecto, el poeta recurre a la victoria como emblema de legitimación del poder político por parte de los liberales españoles a fin de alcanzar el triunfo sobre los franceses y consumar la libertad. Esta legitimación, no obstante, es necesaria por el impulso que emplea el yo poético al sostener que es necesario "correr" para lograr la entronización de la nación española en lugar de continuar con las tiranías externa e interna. Es interesante, por ello, que el poeta relacionara el texto con la ideología revolucionaria francesa (el uso de la marcha como distintivo de La Marsellesa) para llamar a la libertad de peninsulares y americanos. Se trata de una libertad para el ciudadano español antes que el súbdito peninsular, pues supone que el nuevo sujeto 


\section{El lenguaje político es esencial para comprender cómo se construye el universo mental en la propuesta poética de Olmedo y desentrañar las redes institucionales propuestas desde la Península y el vocabulario que trajo consigo la revolución sociopolítica en ambas orillas del Atlántico.}

que se emana de las libertades individuales y civiles dependerá de cómo se entiendan las leyes que surgirán tras la aprobación de la Constitución de 1812. Y es que, según como se entenderá la libertad hacia inicios del siglo XIX, se afirma que la "libertad natural es el derecho que por naturaleza goza el hombre, para disponer de sí a su albedrío, conforme al fin que fue criado" (Gallardo, 1811; como se citó en Chacón, 2014, p. 141). Con la promulgación de la Constitución de Cádiz surgirá efectivamente la libertad como requisito para la plena consumación de la nación, valor al que canta el poema de Olmedo.

Aunque parezca paradójico, muchos de los reclamos transmitidos por la reunificación eran necesarios para apagar las voces de sedición que empezaban a oírse en el otro lado del Atlántico. La voz del poeta pretende legitimar todavía la pertenencia de estos territorios bajo la tutela del rey y persuade al alocutario de restablecer la presencia de Fernando VII para garantizar el orden perdido. Incluso se menciona el adjetivo que hará conocido a este monarca durante el proceso que tomará la guerra: el "deseado". La construcción del nuevo orden se erigirá con la desaparición del rey del escenario político y social americano para dar paso a un sistema que identificará a los habitantes de las provincias hispánicas ultramarinas con espacios geográficos, políticos y socioculturales propios. En tal sentido, la poesía de Olmedo y de Quintana reflejarán la desarticulación de una monarquía imperial mediante propuestas discursivas que representaban una construcción ficcional que traslada el cuerpo jurídico y político de un soberano omnipotente (el rey) hacia otro con derechos universales: el ciudadano americano.

\section{Conclusiones}

Mientras en "El árbol" se observa todavía la lealtad americana al rey, en "Marcha" se consuma la reproducción de vocablos que se disgregan del espacio político anterior. Paulatinamente, José Joaquín de
Olmedo va alejándose de la estructura monárquica tradicional para ofrecer un aparato legal y jurídico que dé sustento a un modelo que recoja la voz colectiva de la nación. Por ello, el lenguaje político es esencial para comprender cómo se construye el universo mental en la propuesta poética del autor y desentrañar las redes institucionales propuestas desde la Península y el vocabulario que trajo consigo la revolución sociopolítica en ambas orillas del Atlántico tras la irrupción napoleónica.

Esta operación discursiva es utilizada también por Manuel José Quintana para quien la lealtad al rey constituirá, primero, la defensa de la tradición monárquica y, después, la protección de la nación. Esta concepción de entender la desacralización de la imagen del rey permitirá al autor peninsular consolidar no solo una comunidad imaginada a través del rechazo a la invasión francesa, sino la consumación en la identidad nacional. De allí que pueda advertirse en ambos poemas de Quintana la búsqueda de una soberanía distinta del rey y privilegiar el nombre de la nación. El lenguaje político y el programa poético del autor constituyen en efecto el arma discursiva necesaria para retratar el cambio de régimen.

Ambos autores coinciden, por lo tanto, en representar un yo poético que ve en el renovado lenguaje político la tensión de dos sistemas políticos. Olmedo retrata dicha tensión a partir del llamado a los americanos a defender a la nación antes que al rey, lo que representa una irrupción simbólica en el discurso político y en el espacio poético, pues se diluye la sacralización del rey en América. Para Quintana, la transición violenta de un discurso absolutista hacia otro liberal gira en torno a un sistema que necesita regenerar la imagen del rey. Se trata entonces de un yo poético que describe una situación tensiva entre dos lenguajes políticos enfrentados por una crisis institucional, la cual había sido provocada por la misma monarquía, por lo que la nación se erige como la comunidad que debe congregar directamente a los sujetos sin intermediación del rey. 


\section{Notas}

1 Existe una teoría política acerca de los dos cuerpos del rey en el mundo hispánico, los cuales debían ser advertidos por los vasallos a través de una corte y una estructura regia similar a la peninsular (en América el virrey). "Esta dicotomía, virreyes próximos y poderosos, monarcas lejanos pero omnipresentes, va a marcar las relaciones de poder y de dependencia del gobierno español en las colonias americanas" (Mínguez, 1995, p. 26).

2 Es interesante recalcar esta definición, ya que la dicotomía salvaje/civilizado nacerá con la llustración.

3 La primera versión de este poema apareció con el título de "A España, en abril de $1808^{\prime \prime}$.

4 Precisamente, la categoría "independiente" que le atribuye la Constitución a la monarquía consolidó la ruptura de esta con las pretensiones napoleónicas de incorporar la Península a su imperio, factor que distanciaba definitivamente a los liberales de los afrancesados (Moreno, 2011, p. 128).

5 Mínguez (2004) destaca que también hubo representaciones leoninas en América durante el periodo borbónico, pues se solía entender que el animal se fusionaba con la identidad hispánica (pp. 80-81).

6 Esta imagen de homogeneidad del espacio imperial ante la lectura del vate irá desvaneciéndose en los siguientes poemas. La construcción unificadora de un reino de Indias, como se pretendía describir en la Península, ayudó a tergiversar la visión que se tenía de América, lo que se demostró en las Cortes al cotejarse la mutua ignorancia que exponían los diputados de una u otra provincia hispánica.

7 Quienes redactaron la Constitución de Cádiz fueron muy enfáticos al establecer, en el artículo $172 .^{\circ}$, las atribuciones que le correspondían al rey y a qué prohibiciones estaba sometido, especialmente en su relación con las Cortes y los antiguos privilegios. Se establecieron en total doce restricciones (Moreno, 2011, pp. 287-289).

8 Las dos últimas estrofas fueron tomadas por Olmedo del poema "Canto guerrero para los asturianos" (1810) de Jovellanos.

9 Esta mirada se opondría a la propuesta que expuso el propio Olmedo acerca del trabajo en las mitas impuesto a los indígenas en el virreinato del Perú. Según su posición de diputado elegido por el Perú en las Cortes de Cádiz, los indios estaban sometidos a una imposición de trabajo prácticamente esclavizante, del cual puede decirse que "el principio de la mita se opone a la libertad de los indígenas reconocida por las leyes; la mita arranca brazos a la agricultura, desarraiga a los individuos y destruye las familias: es una causa importante de despoblación; en la antigüedad, el trabajo en las minas era el castigo más duro al que se condenaba a los criminales, castigo que la mita impone a hombres inocentes" (Rieu-Millan, 1990, p. 124). En realidad, los diputados gaditanos, especialmente los americanos, estuvieron de acuerdo con eliminar las actividades de explotación contra los indios, a pesar de que los propietarios de minas y de latifundios mostraron su oposición, pues afectaba la producción (p. 123). Rieu-Millan (1990) asegura que Olmedo desconocía el funcionamiento de la mita, por lo que su disertación en las Cortes se basó en los comentarios que oyera probablemente en Lima (p. 124). Quizá esta inexperiencia acerca de las actividades destinadas a la población nativa como de los individuos que componían estas mismas colectividades le impidió incorporar una visión andina en sus producciones líricas. Además, la mirada ilustrada excluía a las comunidades no-europeas, por cuanto su participación (si se producía) era interpretada solo por aquellos que estaban familiarizados con la cultura occidental. Por ello, no es de sorprender que la participación indígena en la elección de las Cortes no fuese totalmente abierta, ya que "eran considerados como representables y elegibles, pero el sistema elaborado para América aseguraba la inferioridad numérica de su representación y apartaba prácticamente a los indios de ejercicio electoral" (Rieu-Millan, 1990, p. 111).

10 Esta estrofa también fue tomada por Olmedo del poema "Canto guerrero para los asturianos" (1810) de Jovellanos.

11 La traducción es mía. 


\section{Referencias bibliográficas}

Ahmed, S. (2017). La política cultural de las emociones. Ciudad de México: Universidad Nacional Autónoma de México.

Aljovín, C. (2009). América. Perú. En J. Fernández Sebastián (Dir.), Diccionario político y social del mundo iberoamericano. La era de las revoluciones. Iberconceptos I (pp. 142-152). Madrid: Fundación Carolina, Centro de Estudios Políticos y Constitucionales.

Annino, A. (1995). Cádiz y la revolución territorial de los pueblos mexicanos, 1812-1821. En A. Annino (Coord.), Historia de las elecciones en Iberoamérica, siglo XIX. De la formación del espacio político nacional (pp. 177-226). Buenos Aires: Fondo de Cultura Económica.

Annino, A. (2003). Soberanías en lucha. En A. Annino y F.-X. Guerra (Coords.), Inventando la nación. Iberoamérica, siglo XIX (pp. 152-184). Ciudad de México: Fondo de Cultura Económica.

Berruezo, M. T. (1986). La participación americana en las Cortes de Cádiz (1810-1814). Madrid: Centro de Estudios Constitucionales.

Brading, D. A. (2003). La monarquía católica. En A. Annino, \& F. X. Guerra (Coords.), Inventando la nación. Iberoamérica, siglo XIX (pp. 15-46). México: Fondo de Cultura Económica.

Burke, P. (2011). The fabrication of Louis XIV. New Haven: Yale University Press.

Chacón, P. J. (2014). Libertad. España. En L. González-Ripoll y G. Entin (Eds.), Libertad. En J. Fernández (Dir.), Diccionario político y social del mundo iberoamericano. Conceptos políticos fundamentales, 1770-1870. Iberconceptos II. Tomo 5 (pp. 139152). Madrid: Universidad del País Vasco, Centro de Estudios Políticos y Constitucionales

Demélas, M. D. (2003). La invención política. Bolivia, Ecuador, Perú en el siglo XIX. Lima: Instituto Francés de Estudios Andinos, Instituto de Estudios Peruanos.

Fernández, J. (2014). Civilización. España. En J. Feres Júnior (Ed.), Civilización. En J. Fernández (Dir.), Diccionario político y social del mundo iberoamericano. Conceptos políticos fundamentales, 1770-1870. Iberconceptos II, Tomo 1 (pp. 201216). Madrid: Universidad del País Vasco, Centro de Estudios Políticos y Constitucionales.

Fernández, J. y Fuentes, J. F. (Dirs.). (2002). Diccionario político y social del siglo XIX español. Madrid: Alianza.

Fernández, J. y Suárez, C. (2014). Independencia. España. En A. San Francisco (Ed.), Independencia. En J. Fernández (Dir.), Diccionario político y social del mundo iberoamericano. Conceptos políticos fundamentales, 1770-1870. Iberconceptos II, Tomo 4 (pp. 127-142). Madrid: Universidad del País Vasco, Centro de Estudios Políticos y Constitucionales.

Guerra, F.-X. (2003). El ocaso de la monarquía hispánica: revolución y desintegración. En A. Annino y F.-X. Guerra (Coords.), Inventando la nación. Iberoamérica, siglo XIX (pp. 117-151). Ciudad de México: Fondo de Cultura Económica.

Guerra, F.-X. (2014). Modernidad e independencias. Ensayos sobre las revoluciones hispánicas. Ciudad de México: Mapfre, Fondo de Cultura Económica.

Lomné, G. (2014). El feliz momento de la patria. En G. Lomné (Ed.), Patria. En J. Fernández (Dir.), Diccionario político y social del mundo iberoamericano. Conceptos políticos fundamentales, 1770-1870. Iberconceptos II, Tomo 8 (pp. 15-36). Madrid: Universidad del País Vasco, Centro de Estudios Políticos y Constitucionales.

Maravall, J. A. (2012). La cultura del barroco. Análisis de una estructura histórica. Madrid: Ariel.

Maravall, J. A. (2013). El concepto de España en la Edad Media. Madrid: Centro de Estudios Políticos y Constitucionales.

McEvoy, C. (2009). República. Perú. En J. Fernández (Dir.), Diccionario político y social del mundo iberoamericano. La era de las revoluciones. Iberconceptos I (pp. 1345-1356). Madrid: Fundación Carolina, Centro de Estudios Políticos y Constitucionales.

Mínguez, V. (1995). Los reyes distantes. Imágenes del poder en el México virreinal. Castelló de la Plana: Publicacions de la Universitat Jaume I. 
Mínguez, V. (2001). Los reyes solares. Iconografía astral de la monarquía hispánica. Castelló de la Plana: Publicacions de la Universitat Jaume I.

Mínguez, V. (2004). Leo fortis, rex fortis. El león en la monarquía hispánica. En V. Mínguez y M. Chust (Eds.), El imperio sublevado. Monarquía y naciones en España e Hispanoamérica (pp. 57-94). Madrid: Consejo Superior de Investigaciones Científicas.

Mínguez, V. (2010). Los últimos reyes atlánticos: ocasos imperiales e iconografías de Fernando VII, George III y João VI. En M. E. Linhares y V. Mínguez (Eds.), La fabricación visual del mundo atlántico, 1808-1940 (pp. 11-27). Castelló de la Plana: Publicacions de la Universitat Jaume I.

Moreno, M. (2011). La Constitución de Cádiz. Una mirada crítica. Sevilla: Alfar.

Olmedo, J. J. de. (1947). Poesías completas (A. Espinosa, Ed.). Buenos Aires: Fondo de Cultura Económica.

Ossa, J. L. (2014). De Cádiz a la América del Sur. El viaje de una ilusión constitucional. En A. De Francesco, L. Mascilli y R. Nocera (Coords.), Entre Mediterráneo y Atlántico. Circulaciones, conexiones y miradas, 1756-1867 (pp. 255-278). Santiago: Fondo de Cultura Económica.

Paniagua, V. (2003). Los orígenes del gobierno representativo en el Perú. Las elecciones (1809-1826). Lima: Fondo Editorial de la Pontificia Universidad Católica del Perú, Fondo de Cultura Económica.

Portillo, J. M. (2006). Crisis atlántica. Autonomía e independencia en la crisis de la monarquía hispánica. Madrid: Marcial Pons, Centro de Estudios Hispánicos e lberoamericanos.

Portillo, J. M. y Serván, C. (2014). Soberanía. España. En N. Goldman (Ed.), Soberanía. En: J. Fernández (Dir.), Diccionario político y social del mundo iberoamericano. Conceptos políticos fundamentales, 1770-1870. Iberconceptos II, Tomo 10 (pp. 33-48). Madrid: Universidad del País Vasco, Centro de Estudios Políticos y Constitucionales.

Quintana, M. J. (2001). Poesías completas, Edición de A. Dérozier. Madrid: Castalia.

Rico, R. (2009). Manuel José Quintana: la patria poética como revolución. En F. Durán, A. Romero y M. Cantos (Eds.), La patria poética. Estudios sobre literatura y política en la obra de Manuel José Quintana (pp. 219-255). Madrid: Iberoamericana, Vervuert.

Rieu-Millan, M. L. (1990). Los diputados americanos en las Cortes de Cádiz (lgualdad o independencia). Madrid: Consejo Superior de Investigaciones Científicas.

Sá e Melo, F. (2009). Entre viejos y nuevos sentidos: "Pueblo" y "pueblos" en el mundo iberoamericano, 1750-1850. En J. Fernández (Dir.), Diccionario político y social del mundo iberoamericano. La era de las revoluciones. Iberconceptos I (pp. 1117-1138). Madrid: Fundación Carolina, Centro de Estudios Políticos y Constitucionales.

Seoane, J. (2015). El otro que no somos nosotros. La idea del salvaje que sirvió para componer los Estados Unidos y la Escocia del XVIII. En M. J. Villaverde y G. López Sastre (Eds.), Civilizados y salvajes. La mirada de los ilustrados sobre el mundo no europeo (pp. 113136). Madrid: Centro de Estudios Políticos y Constitucionales.

Thompson, E. P. (2019). Costumbres en común. Estudios sobre la cultura popular. Madrid: Capitán Swing.

Tomás y Valiente, F. (2011). Génesis de la Constitución de 1812, I. De muchas leyes fundamentales a una sola constitución. Pamplona: Urgoiti.

Urquijo, P. (2020). Paisaje cultural, un enfoque pertinente. En P. Urquijo y A. Boni (Coords.), Huellas en el paisaje. Geografía, historia y ambiente en las Américas (pp. 17-37). Ciudad de México: Universidad Autónoma de México, Centro de Investigaciones en Geografía Ambiental. https://www.researchgate.net/publication/340825936_Paisaje_cultural_un_enfoque_ pertinente

Varela, J. (2011). La teoría del Estado en las Cortes de Cádiz. Orígenes del constitucionalismo hispano. Madrid: Centro de Estudios Políticos y Constitucionales.

Varela, J. (2013). La monarquía doceañista (1810-1837). Avatares, encomios y denuestos de una extraña forma de gobierno. Madrid: Marcial Pons.

Velásquez, D. (2014). Patria. Perú. En G. Lomné (Ed.), Patria. En: J. Fernández (Dir.), Diccionario político y social del mundo iberoamericano. Conceptos políticos fundamentales, 1770-1870. Iberconceptos II, Tomo 8 (pp. 165-179). Madrid: Universidad del País Vasco, Centro de Estudios Políticos y Constitucionales

Velázquez, M. (2013). La mirada de los gallinazos. Cuerpo, fiesta y mercancía en el imaginario sobre Lima (1640-1895). Lima: Fondo Editorial del Congreso del Perú. 